\title{
Bioactive Phenolic Metabolites from Adriatic Brown Algae Dictyota dichotoma and Padina pavonica (Dictyotaceae)
}

\author{
Ivana Generalić Mekinić ${ }^{1, *(D)}$, Vida Šimat ${ }^{2, *}$ D, Viktorija Botić ${ }^{1}$, Anita Crnjac ${ }^{1}$, Marina Smoljo ${ }^{1}$, Barbara Soldo ${ }^{3}$, \\ Ivica Ljubenkov ${ }^{3} \mathbb{D}$, Martina Čagalj ${ }^{2}$ and Danijela Skroza ${ }^{1} \mathbb{C}$
}

1 Department of Food Technology and Biotechnology, Faculty of Chemistry and Technology, University of Split, R. Boškovića 35, HR-21000 Split, Croatia; viktorijabotic9@gmail.com (V.B.); anitaaklanac@gmail.com (A.C.); marinasmoljo.1@gmail.com (M.S.); danci@ktf-split.hr (D.S.)

2 Department of Marine Studies, University of Split, R. Boškovića 37, HR-21000 Split, Croatia; martina.cagalj@unist.hr

3 Department of Chemistry, Faculty of Science, University of Split, R. Boškovića 33, HR-21000 Split, Croatia; barbara@pmfst.hr (B.S.); ivica.ljubenkov4@gmail.com (I.L.)

* Correspondence: gene@ktf-split.hr (I.G.M.); vida@unist.hr (V.Š.); Tel.: +385-21329458 (I.G.M.); +385-21510192 (V.Š.)

Citation: Generalić Mekinić, I.; Šimat, V.; Botić, V.; Crnjac, A.; Smoljo, M.; Soldo, B.; Ljubenkov, I.; Čagalj, M.; Skroza, D. Bioactive Phenolic Metabolites from Adriatic Brown Algae Dictyota dichotoma and Padina pavonica (Dictyotaceae). Foods 2021, 10, 1187. https://doi.org/10.3390/ foods10061187

\section{Academic Editors:}

Oscar Martinez-Alvarez and Maria Elvira López-Caballero

Received: 27 April 2021

Accepted: 23 May 2021

Published: 25 May 2021

Publisher's Note: MDPI stays neutral with regard to jurisdictional claims in published maps and institutional affiliations.

Copyright: (c) 2021 by the authors. Licensee MDPI, Basel, Switzerland. This article is an open access article distributed under the terms and conditions of the Creative Commons Attribution (CC BY) license (https:// creativecommons.org/licenses/by/ $4.0 /)$
Abstract: In this study, the influences of temperature $\left(20,40\right.$ and $60^{\circ} \mathrm{C}$ ) and extraction solvents (water, ethanol) on the ultrasound-assisted extraction of phenolics from the Adriatic macroalgae Dictyota dichotoma and Padina pavonica were studied. The extracts were analysed for major phenolic subgroups (total phenolics, flavonoids and tannins) using spectrometric methods, while the individual phenolics were detected by HPLC. The antioxidant activities were evaluated using three methods: Ferric Reducing/Antioxidant Power (FRAP), scavenging of the stabile 2,2-diphenyl-1-picrylhydrazyl (DPPH) radical and Oxygen Radical Antioxidant Capacity (ORAC). The aim of the study was also to find the connection between the chemical composition of the extracts and their biological activity. Therefore, principal component analysis (PCA), which permits simple representation of different sample data and better visualisation of their correlations, was used. Higher extraction yields of the total phenolics, flavonoids and tannins were obtained using an alcoholic solvent, while a general conclusion about the applied temperature was not established. These extracts also showed good antioxidant activity, especially $D$. dichotoma extracts, with high reducing capacity $(690-792 \mathrm{mM}$ TE) and ORAC values (38.7-40.8 mM TE in 400-fold diluted extracts). The PCA pointed out the significant influence of flavonoids and tannins on the investigated properties. The results of this investigation could be interesting for future studies dealing with the application of these two algae in foods, cosmetics and pharmaceuticals.

Keywords: antioxidants; biological activity; brown seaweeds; extraction mode; phenolic compounds

\section{Introduction}

Macroalgae (seaweeds), which are organisms that inhabit marine or freshwater habitats, have attracted the interest of researchers as they are a proven source of various biologically active metabolites. These components are generated as a protection against free radicals or other oxidizing substances that affect macroalgae since they are exposed to adverse environmental conditions [1-5].

Based on their photosynthetic pigment type, type of storage material and composition of cell wall polysaccharides, macroalgae are usually divided into three groups: green, red and brown algae [6,7]. Brown algae constitute the largest class (with up to 2000 species) [8] and are probably the most investigated, as these species contain a special group of biologically active phenolics called phlorotannins $[7,9]$. The phenolic compounds present in brown algae species are derived from polymerised phloroglucinol units via the acetate malonate pathway [10]. Phlorotannins play a role in protecting algae against herbivores, 
bacteria and fouling organisms. They are also involved in protection against oxidative damage, as their antioxidant activity is 10 to 100 times more powerful than that of other polyphenols [11,12]. They have also been broadly investigated since they have a large spectrum of positive biological properties such as UV protective actions and anti-inflammatory, anti-angiogenic, anti-allergic and antidiabetic effects $[13,14]$. Phlorotannins exist in soluble or in cell-wall-bound forms. Based on the number and distribution of hydroxyl groups and the nature of the structural linkages between phloroglucinol units, they can be divided into phlorethols, fuhalols, fucols, fucophlorethols and eckols $[5,12,15,16]$. Seaweeds are also an excellent source of other biologically active compounds such as polysaccharides (fucoidan, laminarin and alginates), peptides, polyunsaturated fatty acids, pigments (carotenoids), minerals, sterols, etc. $[17,18]$.

In recent decades, great attention has been devoted to the search for new, bioactivecompound-rich and inexpensive natural sources of valuable phytochemicals with beneficial biological activities. Seaweeds from diverse habitats have great potential due to their valuable nutritional profile, low caloric value and medicinal benefits. They are often used as vegetables (fresh or dried) and/or ingredients in numerous dishes, and they are also often used as valuable ingredients in the formulation of functional foods [17-19]. The brown macroalgae Dictyota dichotoma and Padina pavonica (Dictyotaceae) are species widespread in the Adriatic Sea, but there are limited or scarce data on their chemical composition [20,21], especially their phenolic content [22]. Due to the long duration and application of high temperatures in conventional extraction protocols, negative effects on their health-promoting components are often observed. Therefore, there is an increasing trend toward the investigation of novel, environmentally friendly extraction technologies for the preparation of highly valuable extracts. Among the different new technologies, the use of ultrasound-assisted extraction is probably one of the easiest, cheapest and, consequently, most widely used $[5,15,18,23]$.

The aim of this study was to investigate the biological potential of $D$. dichotoma and P. pavonica and the impact of the extraction mode (ultrasound, solvent and temperature regime) on their phenolic profile. Furthermore, the connection between the phenolic profile of the algae and related activity was investigated in order to find the extraction parameters best suited for producing bioactive extracts.

\section{Materials and Methods}

\subsection{General}

All chemicals, reagents and solvents used were of adequate analytical grade and were obtained from Kemika (Zagreb, Croatia) and Sigma-Aldrich (St. Louis, MO, USA). Spectrophotometric measurements were performed on a SPECORD 200 Plus, Edition 2010 (Analytik Jena AG, Jena, Germany) and a Synergy HTX Multi-Mode Reader (BioTek Instruments, Inc., Winooski, VT, USA). The high-performance liquid chromatography (HPLC) system used was the Perkin Elmer Series 200 with a UV/VIS detector (Perkin-Elmer Inc., Shelton, CT, USA), and the phenolic compounds were separated on an UltraAqueous column $(\mathrm{C} 18,250 \times 4.6 \mathrm{~mm}, 5 \mathrm{~mm}$, Restek, Bellefonte, PA, USA).

\subsection{Seaweed Material and Preparation of Extracts}

Seaweed materials, Dictyota dichotoma (Hudson) J. V. Lamouroux and Padina pavonica (L.) Gaill. were collected in August 2020 on the coast of Čiovo Island (Central Dalmatia, Croatia, $43.523492^{\circ} \mathrm{N}, 16.285571^{\circ}$ E). Zvjezdana Popović Perković, a marine botanist from the University of Split's Department of Marine Studies, confirmed the botanical identity of the algal materials. The algal biomass was harvested by hand and then washed thoroughly with fresh water to remove epiphytes. The materials (algae thalli) were air-dried for 15 days in a shaded and aerated place at room temperature, and then, they were pulverised ( $1 \mathrm{~min}$ in high-speed grinder, Model 980, Moulinex, France) and used for the preparation of extracts. 
The algal extracts were prepared by ultrasound-assisted extraction (Sonorex RK 103H, Bandelin, Berlin, Germany) using different solvents: ethanol and water at three different temperatures of 20 (room temperature, RT), 40 and $60{ }^{\circ} \mathrm{C}$. For algal extracts, $1 \mathrm{~g}$ of dried and ground samples was weighed and $10 \mathrm{~mL}$ of solvent was added. The duration of the extraction was $1 \mathrm{~h}$, following which the suspensions were filtered and centrifuged (10 min, $4000 \mathrm{rpm}$, Centric $322 \mathrm{~A}$, Tehtnica, Slovenia). Extractions were carried out in three repetitions for each plant material, and all sample extracts were combined in a total extract that was used for further analysis.

\subsection{Phenolic Composition}

\subsubsection{Spectrophotometric Analysis of Phenolic Subgroups}

The total phenolic content in samples was determined by the Folin-Ciocalteu method [24] and the results are expressed as mg of gallic acid equivalents per litre of extract (mg GAE/L).

Total flavonoids were determined using the colorimetric method reported by Yang et al. [25]. The results are expressed as $\mathrm{mg}$ of quercetin equivalents per litre of extract (mg QE/L).

Tannins were detected using vanillin- $\mathrm{HCl}$ according to the procedure described by Julkunen-Titto [26]. In this assay, catechin was used as the standard and the results are expressed as $\mathrm{mg}$ catechin equivalents per litre of extract (mg CE/L).

\subsubsection{HPLC Analysis of Individual Phenolics}

For the separation, quantification and identification of individual phenolics, the HPLC method was used. The method was described in the study of Generalić Mekinić et al. [27]. The flow rate was $0.8 \mathrm{~mL} / \mathrm{min}$ and the signal was monitored at $280 \mathrm{~nm}$. The following solvents were used: solvent A was water/phosphoric acid (99.8:0.2, v/v) and solvent B was methanol/acetonitrile (50:50, $v / v)$. The detected phenolic acids were identified by comparing their retention times and absorption spectra with those acquired for corresponding standards and by sample spiking. The compounds were quantified using external standard calibration curves. Phloroglucinol was detected using the same method but the signal was monitored at $267 \mathrm{~nm}$, where the maximal absorption spectrum of this compound has been recorded. The results are expressed as $\mathrm{mg}$ of compound per litre of extract $(\mathrm{mg} / \mathrm{L})$.

\subsection{Antioxidant Activity}

\subsubsection{Ferric Reducing/Antioxidant Power (FRAP)}

The reducing activity of the samples was measured as FRAP value according to the procedure reported by Benzie and Strain [28]. This method is used to measure the ability of samples to reduce ferric-tripyridyltriazine $\left(\mathrm{Fe}^{3+}-\mathrm{TPTZ}\right)$ to a ferrous-tripyridyltriazine complex $\left(\mathrm{Fe}^{2+}\right.$-TPTZ) at a low $\mathrm{pH}$ value (3.6). Diluted extracts $(10 \mu \mathrm{L})$ were added to a freshly prepared FRAP reagent $\left(300 \mathrm{mM}\right.$ acetate buffer:TPTZ in $40 \mathrm{mM} \mathrm{HCl}: 20 \mathrm{mM} \mathrm{FeCl}_{3}$ $\left.\times 6 \mathrm{H}_{2} \mathrm{O}=10: 1: 1\right)(300 \mu \mathrm{L})$ and the absorbances were measured at $593 \mathrm{~nm}$. The results obtained by this method are expressed in millimoles of Trolox equivalents per litre (mM TE) [25].

\subsubsection{Radical 2,2-Diphenyl-1-picrylhydrazyl (DPPH)}

The free radical scavenging activity against DPPH. was determined according to the procedure described by Katalinić et al. [29]. The decrease in absorbance of the initial DPPH solution $(300 \mu \mathrm{L})$ after addition of the sample $(10 \mu \mathrm{L})$ was monitored at $517 \mathrm{~nm}$ after $1 \mathrm{~h}$. The results of the "quenching" reactions of antioxidants with DPPH are expressed in micromoles of Trolox equivalents per litre ( $\mu \mathrm{M}$ TE).

\subsubsection{Oxygen Radical Antioxidant Capacity (ORAC)}

An ORAC assay was performed according to the procedure described by Generalić Mekinić et al. [27]. For the measurements, $25 \mu \mathrm{L}$ of the diluted sample/phosphate buffer (blank)/standard (Trolox) was added to a well of a black 96-well plate. After that, $150 \mu \mathrm{L}$ 
of the fluorescein was added, and after incubation for $30 \mathrm{~min}, 25 \mu \mathrm{L}$ of the 2,2'-azobis(2methylpropionamidine) dihydrochloride solution was added to initiate the reaction. The reaction was monitored every minute for $80 \mathrm{~min}$, and the results are expressed as $\mathrm{mM} \mathrm{TE}$.

\subsection{Statistical Analysis}

For data analysis, STATISTICA (Data Analysis Software System, v. 13, StatSoft Inc., Tulsa, OK, USA) was used. Pearson's correlation coefficient and principal component analysis (PCA) were used for determining the relations between the variables. All data are expressed as mean \pm standard deviation (SD).

\section{Results and Discussion}

Phenolic compounds are plant secondary metabolites, and the isolation, characterisation and investigation of their biological activities have been the aim of much research. Generally, phenolics, but also the subgroup of phlorotannins, which are the dominant brown algal phenolics, are proven to have positive pharmacological and nutraceutical properties $[2,12,14]$. These health-promoting activities of phenolics are critical for neutralising the effects of oxidizing agents (such as free radicals) that are generated during metabolism due to exposure to extreme conditions (e.g., UV radiation, salinity, temperature, high oxygen concentrations, etc.). The concentration of phenolics in brown algae is influenced by different abiotic and biotic factors, while their analysis is influenced by their chemical nature, the applied extraction procedure, storage conditions, the presence of interfering substances, etc. [5,30]. In this study, different extraction modes were used to obtain the most effective algae extracts with the highest share of phenolics. Recent trends in algal research have also focused on the investigation and application of innovative technologies in improving the extraction efficiencies, and ultrasound-assisted extraction is a low-cost method that is often used [5,18,31,32].

As it is well known that the extraction rate may be improved by the modification of process variables, the ultrasound-assisted extractions of algal samples were performed at different temperatures $\left(20,40\right.$ and $60^{\circ} \mathrm{C}$ ) and using different solvents (water and ethanol). The compound chemical nature is a restricting factor in finding a suitable extraction solvent system [5]. Although researchers use various organic solvents in order to obtain extracts with a high share of phenolics [3,27-30,32], water and ethanol are preferred in the food, pharmaceutical and cosmetic industries due to economic, toxicological and environmental reasons [33]. Due to variations in the polarity of the phenolic compounds, it is expected that hydroalcoholic mixtures could be the most suitable solvents. This is confirmed by the results of this study, as a better extraction yield was obtained using alcoholic solvents in contrast to water solvents. Figure 1 shows the total contents of phenolics, flavonoids and tannins in extracts of D. dichotoma and P. pavonica.

The total phenolic content ranged from $127 \mathrm{mg} \mathrm{GAE} / \mathrm{L}$ in the water extract of $D$. dichotoma prepared at $40{ }^{\circ} \mathrm{C}$, to $423 \mathrm{mg} \mathrm{GAE} / \mathrm{L}$ in the ethanolic extract of P. pavonica. Although the use of high temperatures usually leads to a kinetic improvement, it is often limited by the fact that most phenolics are not thermostable, so heat treatments could reduce the total extracted amount [34]. Garcia-Vaquero et al. [31] also reported that ultrasoundassisted extraction at $40^{\circ} \mathrm{C}$ (for $30 \mathrm{~min}$ ) resulted in phenolic extracts with the highest yield and maximal antioxidant capacity. As can be seen from the obtained results, the extracts prepared at RT in all cases, except for ethanolic extracts of $P$. pavonica, yielded the highest amount. The share of phenolics in the ethanolic extracts of $D$. dichotoma prepared at RT was $29 \%$ higher than that in the water extracts, and $56 \%$ and $46 \%$ higher in the ethanolic extracts prepared at 40 and $60{ }^{\circ} \mathrm{C}$, respectively. Although there were no significant differences between the phenolic potential of the $D$. dichotoma and P. pavonica water extracts, the content of phenolics in the ethanolic extracts was significantly higher. Other authors also investigated phenolics from $D$. dichotoma $[2,23,34-36]$ and P. pavonica $[3,22,23,33,34]$, but comparison of the results is difficult due to the employment of different extraction protocols (solvents used, time of extraction, temperature, additional actions such as stirring, use of 
novel techniques, etc.) or due to results' expression using different standard compounds. However, the results of our study on the influence of drying and extraction methods on $P$. pavonica phenolics showed better extraction yields in water extracts (more than twofold higher results were obtained) [23]. Figure $1 \mathrm{~b}$ also shows the distribution of flavonoids among samples. It can be seen that the ethanolic extracts are richer in these valuable compounds, especially extracts of $D$. dichotoma (concentration range from $871 \mathrm{mg} Q E / \mathrm{L}$ in extract prepared at $60^{\circ} \mathrm{C}$ to $975 \mathrm{mg}$ QE/L in extract prepared at RT). Kosanic et al. [22] also reported a higher content of flavonoids in extracts of D. dichotoma than in P. pavonica, while Čagalj et al. [23] obtained a higher content of flavonoids in ethanolic extracts. All other samples contained significantly lower amounts, from 23 to $160 \mathrm{mg}$ QE/L. Similar results were obtained for the total tannins (Figure 1c), where, again, the highest amounts of these compounds were detected in the ethanolic extracts of $D$. dichotoma (from 0.34 to $0.39 \mathrm{mg} \mathrm{CE} / \mathrm{L})$.

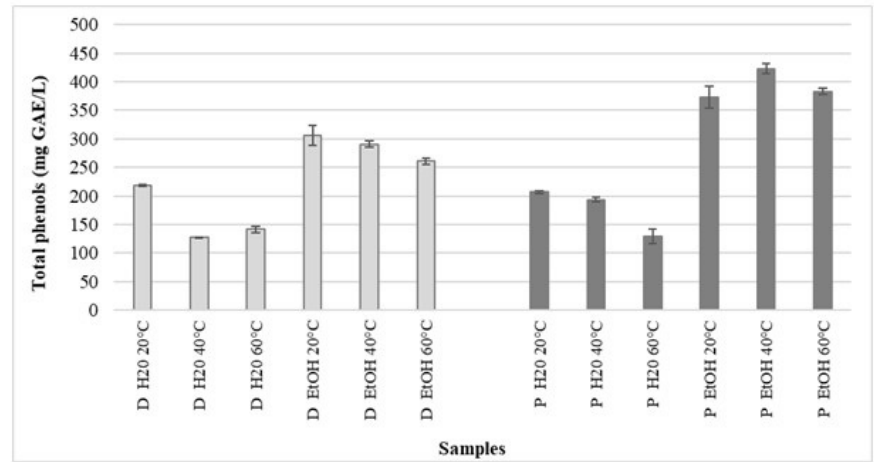

a)

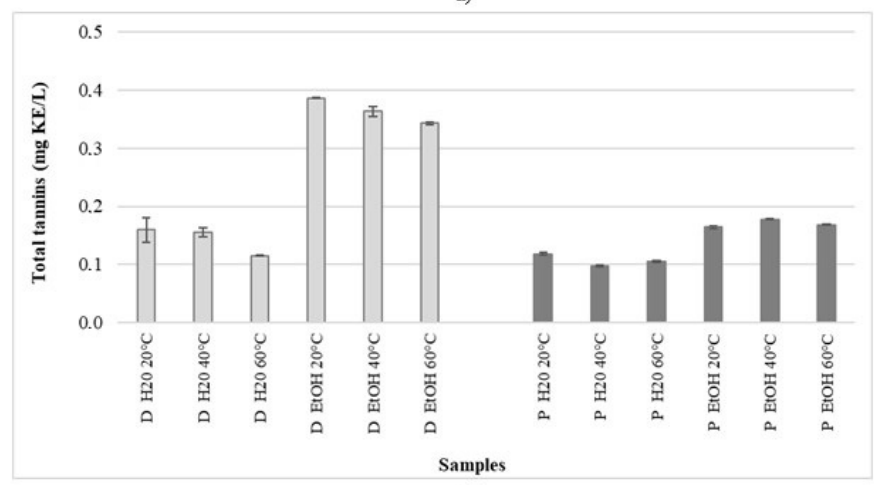

c)

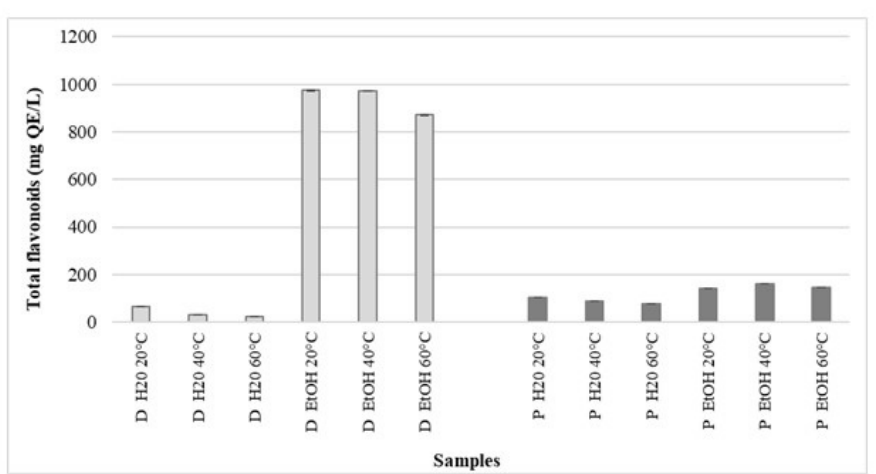

b)

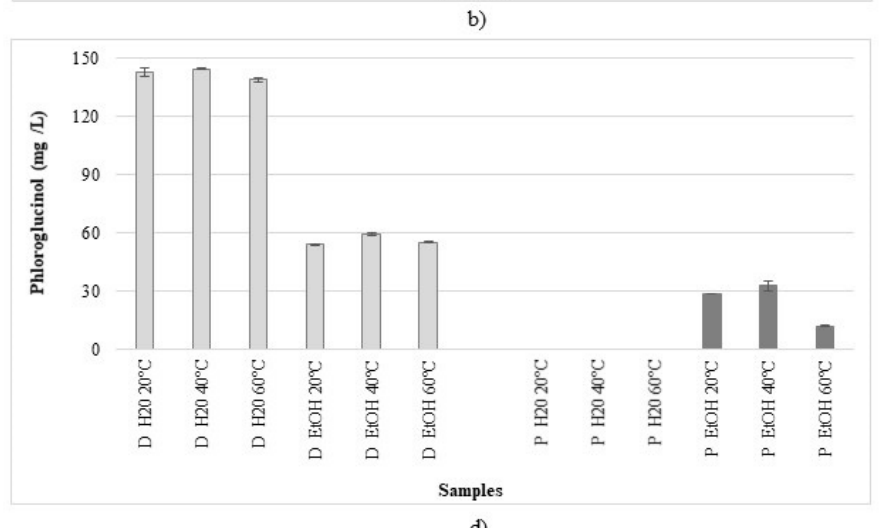

d)

Figure 1. Total contents of (a) phenolics, (b) flavonoids, (c) tannins and (d) phloroglucinol in Dictyota dichotoma (D) and Padina pavonica (P) extracts.

The individual phenolic acids in the D. dichotoma and P. pavonica extracts detected by HPLC are presented in Table 1, while the phloroglucinol content is shown in Figure 1d. According to the presented results, the dominant phenolic acid in the extracts of $D$. dichotoma was trans-ferulic acid, with the highest concentrations in the ethanolic extract prepared at RT. In P. pavonica, the dominant phenolic was protocatechuic acid. Although trans-ferulic acid was also found in the P. pavonica extracts, its concentration was only significant in the water extract prepared at RT $(1.22 \mathrm{mg} / \mathrm{L})$. While the levels of $o$-coumaric acid in the $P$. pavonica extracts were low in all samples, the concentrations of its para-isomer were significantly higher in the ethanolic extracts than in the water extracts. Similar results were obtained in the $D$. dichotoma extract, where the highest concentration was detected in the ethanolic extract prepared at $20^{\circ} \mathrm{C}(2.07 \mathrm{mg} / \mathrm{L})$. Generally, the concentrations of hydroxycinnamic acid derivatives ( $p$-coumaric, $o$-coumaric and $t$-ferulic acid) were higher in the $D$. dichotoma extracts, while the P. pavonica extracts were richer in hydroxybenzoic (protocatechuic and $p$-hydroxybenzoic) acids. According to the results for phloroglucinol 
content (Figure 1d), it is apparent that the D. dichotoma extracts were richer in this substance, with an almost threefold higher content in the water extracts than in the EtOH extracts. On the other hand, the P. pavonica ethanolic extracts contained significantly lower amounts of phloroglucinol, while its quantification in the water extracts was not possible (it was present, but at an amount below the quantification limit).

Table 1. Phenolic acids in Dictyota dichotoma (D) and Padina pavonica (P) extracts detected by HPLC.

\begin{tabular}{|c|c|c|c|c|c|c|}
\hline \multirow[b]{2}{*}{ Sample } & \multicolumn{6}{|c|}{ Compound Concentration (mg/L of Algal Extract) } \\
\hline & $\begin{array}{c}\text { Protocatechuic } \\
\text { Acid }\end{array}$ & $\begin{array}{c}p \text {-hydroxybenzoic } \\
\text { Acid }\end{array}$ & $\begin{array}{c}p \text {-coumaric } \\
\text { Acid }\end{array}$ & $\begin{array}{l}t \text {-ferulic } \\
\text { Acid }\end{array}$ & $\begin{array}{c}o \text {-coumaric } \\
\text { Acid }\end{array}$ & $\sum$ \\
\hline $\mathrm{D} \mathrm{H}_{2} \mathrm{O} 20^{\circ} \mathrm{C}$ & $0.62 \pm 0.05$ & $0.22 \pm 0.04$ & $1.00 \pm 0.02$ & $1.41 \pm 0.15$ & $0.16 \pm 0.01$ & 3.41 \\
\hline $\mathrm{D} \mathrm{H}_{2} \mathrm{O} 40^{\circ} \mathrm{C}$ & $0.05 \pm 0.01$ & $0.19 \pm 0.02$ & $0.72 \pm 0.01$ & $1.28 \pm 0.10$ & $0.10 \pm 0.01$ & 2.34 \\
\hline $\mathrm{D} \mathrm{H}_{2} \mathrm{O} 60^{\circ} \mathrm{C}$ & $0.30 \pm 0.00$ & $0.13 \pm 0.01$ & $0.44 \pm 0.02$ & $0.68 \pm 0.02$ & $0.02 \pm 0.00$ & 1.57 \\
\hline $\mathrm{D}$ EtOH $20^{\circ} \mathrm{C}$ & $0.05 \pm 0.00$ & $0.42 \pm 0.05$ & $2.07 \pm 0.20$ & $1.57 \pm 0.07$ & $0.17 \pm 0.01$ & 4.29 \\
\hline $\mathrm{D} \mathrm{EtOH} 40^{\circ} \mathrm{C}$ & $0.23 \pm 0.04$ & $0.30 \pm 0.01$ & $1.75 \pm 0.15$ & $1.37 \pm 0.01$ & $0.14 \pm 0.00$ & 3.78 \\
\hline $\mathrm{D} \mathrm{EtOH} 60^{\circ} \mathrm{C}$ & $0.14 \pm 0.00$ & $0.32 \pm 0.06$ & $1.77 \pm 0.01$ & $1.33 \pm 0.03$ & $0.12 \pm 0.03$ & 3.66 \\
\hline $\mathrm{P} \mathrm{H}_{2} \mathrm{O} 20^{\circ} \mathrm{C}$ & $1.68 \pm 0.03$ & $0.51 \pm 0.56$ & $0.03 \pm 0.00$ & $1.22 \pm 0.10$ & $0.02 \pm 0.00$ & 3.46 \\
\hline $\mathrm{P} \mathrm{H}_{2} \mathrm{O} 40^{\circ} \mathrm{C}$ & $1.70 \pm 0.02$ & $0.60 \pm 0.02$ & $0.02 \pm 0.00$ & $0.07 \pm 0.00$ & $0.03 \pm 0.00$ & 2.42 \\
\hline $\mathrm{P} \mathrm{H}_{2} \mathrm{O} 60^{\circ} \mathrm{C}$ & $1.42 \pm 0.10$ & $0.60 \pm 0.01$ & $0.02 \pm 0.00$ & $0.07 \pm 0.01$ & $0.03 \pm 0.00$ & 1.55 \\
\hline $\mathrm{P} \mathrm{EtOH} 20^{\circ} \mathrm{C}$ & $1.34 \pm 0.03$ & $0.75 \pm 0.02$ & $0.69 \pm 0.07$ & $0.21 \pm 0.01$ & $0.01 \pm 0.01$ & 3.00 \\
\hline $\mathrm{P} \mathrm{EtOH} 40^{\circ} \mathrm{C}$ & $1.05 \pm 0.09$ & $0.76 \pm 0.03$ & $0.79 \pm 0.04$ & $0.24 \pm 0.05$ & $0.02 \pm 0.00$ & 2.86 \\
\hline $\mathrm{P} \mathrm{EtOH} 60^{\circ} \mathrm{C}$ & $1.15 \pm 0.08$ & $0.66 \pm 0.07$ & $0.88 \pm 0.16$ & $0.33 \pm 0.05$ & $0.03 \pm 0.00$ & 3.06 \\
\hline
\end{tabular}

Due to the presence of phlorotannins, it has been reported that brown algae species possess higher antioxidant activity than green and red algae do. It is well known that the concentrations of these compounds vary according to numerous factors, such as species, season, age, geographical location and environmental conditions [7,9]. In this study, antioxidant activity was evaluated by means of a multiple-method approach, using three assays: Ferric Reducing/Antioxidant Power (FRAP), scavenging of the stabile 2,2-diphenyl1-picrylhydrazyl (DPPH) radical and Oxygen Radical Antioxidant Capacity (ORAC). The obtained results are presented in Table 2. According to the presented results for the reducing activity of the samples, the highest activities were detected for the ethanolic extracts of D. dichotoma (from 690 to $792 \mathrm{mM} \mathrm{TE}$ ), while all other samples had more than threefold lower activity. Although in most cases, the antioxidant activity of the samples shows a high correlation with phenolic content, this study only confirmed the significant impact of the flavonoid content on the reducing activity of the extracts $(r=0.9873, p<0.0001)$.

Table 2. Antioxidant activity of Dictyota dichotoma (D) and Padina pavonica (P) extracts detected by the FRAP, DPPH and ORAC methods.

\begin{tabular}{|c|c|c|c|}
\hline Sample & $\begin{array}{c}\text { FRAP } \\
\text { (mM TE) }\end{array}$ & $\begin{array}{c}\text { DPPH } \\
(\mu \mathrm{M} \text { TE })\end{array}$ & $\begin{array}{l}\text { ORAC } \\
\text { (mM TE) }\end{array}$ \\
\hline $\mathrm{D} \mathrm{H}_{2} \mathrm{O} 20^{\circ} \mathrm{C}$ & $139 \pm 16$ & $196 \pm 47$ & $26.7 \pm 2.4$ \\
\hline $\mathrm{D} \mathrm{H}_{2} \mathrm{O} 40^{\circ} \mathrm{C}$ & $147 \pm 3$ & $144 \pm 27$ & $26.6 \pm 1.5$ \\
\hline $\mathrm{D} \mathrm{H}_{2} \mathrm{O} 60^{\circ} \mathrm{C}$ & $232 \pm 7$ & $125 \pm 36$ & $20.6 \pm 4.5$ \\
\hline $\mathrm{D}$ EtOH $20^{\circ} \mathrm{C}$ & $792 \pm 9$ & $113 \pm 31$ & $39.1 \pm 0.8^{*}$ \\
\hline $\mathrm{D} \mathrm{EtOH} 40^{\circ} \mathrm{C}$ & $717 \pm 17$ & $84 \pm 6$ & $40.8 \pm 2.4^{*}$ \\
\hline $\mathrm{D} \mathrm{EtOH} 60^{\circ} \mathrm{C}$ & $690 \pm 21$ & $109 \pm 9$ & $38.7 \pm 2.3$ * \\
\hline $\mathrm{P} \mathrm{H}_{2} \mathrm{O} 20^{\circ} \mathrm{C}$ & $187 \pm 7$ & $30 \pm 10$ & $25.7 \pm 1.2$ \\
\hline $\mathrm{P} \mathrm{H}_{2} \mathrm{O} 40{ }^{\circ} \mathrm{C}$ & $147 \pm 8$ & $84 \pm 6$ & $22.5 \pm 1.9$ \\
\hline $\mathrm{P} \mathrm{H}_{2} \mathrm{O} 60^{\circ} \mathrm{C}$ & $106 \pm 9$ & $56 \pm 11$ & $26.2 \pm 0.8$ \\
\hline $\mathrm{P} \mathrm{EtOH} 20^{\circ} \mathrm{C}$ & $202 \pm 8$ & $501 \pm 66$ & $46.2 \pm 1.4$ \\
\hline $\mathrm{P} \mathrm{EtOH} 40{ }^{\circ} \mathrm{C}$ & $231 \pm 12$ & $595 \pm 13$ & $55.8 \pm 3.0$ \\
\hline $\mathrm{P} \mathrm{EtOH} 60^{\circ} \mathrm{C}$ & $214 \pm 24$ & $645 \pm 25$ & $51.2 \pm 0.7$ \\
\hline
\end{tabular}

* The result obtained for samples deleted 400-times. 
Generally, very low DPPH activity of the samples was detected, with the ethanolic extracts of $P$. pavonica being the most active (from 501 to $645 \mu \mathrm{M}$ TE). Similar results were obtained in the studies of Kosanić et al. [22] and Khaled et al. [35], where the free radical scavenging activities of all three investigated algae species (D. dichotoma, P. pavonica and Sargassum vulgare) were low ( $\mathrm{IC}_{50}$ values significantly higher in comparison to ascorbic acid, BHA and $\alpha$-tocopherol).

Finally, for antioxidant activity measurements, an ORAC assay was also used. This method reflects classical radical chain breaking activity and measures inhibition of peroxylradical-induced oxidation [37]. Again, as can be seen in Table 2, ethanolic extracts were superior in comparison with the water extracts of both algae species. While the activity of the P. pavonica ethanolic extracts was about twofold higher than the activity of the water extracts, the ethanolic extracts of $D$. dichotoma showed excellent activity. In order to obtain results, these extracts were previously diluted to 1:400.

In order to describe and identify the similarities and differences among the samples, a principal component analysis (PCA) was used. The correlation loadings of the first two principal components (PCs) shown in Figure 2 suggest high correlations of the studied parameters. The variables of flavonoids and tannins were strongly characterised by PC1 and showed a high mutual correlation $(r=0.9752, p<0.001)$. Furthermore, those parameters that showed similar characteristics with the FRAP value and $p$-coumaric content in the extracts positively correlated (Figure 2a). The total phenolic content and the free radical scavenging assays (DPPH and ORAC) were characterised by PC2. The first two PCs described $86.81 \%$ of the initial data variability. The score plot (Figure $2 \mathrm{~b}$ ) shows the position of the measured parameters in the multivariate space of the first two PCs. The clear separation between samples indicates the differences between the solvent used and not the applied temperature during the extraction. The water extracts of both algae are grouped in the upper part of the plot, showing no significant difference between them, and are characterised by a low content of phenolics. Based on the contents of flavonoids and tannins, the ethanolic extracts were separated into two opposite parts and, due to the higher phenolics content, are positioned in lower part of the plot.

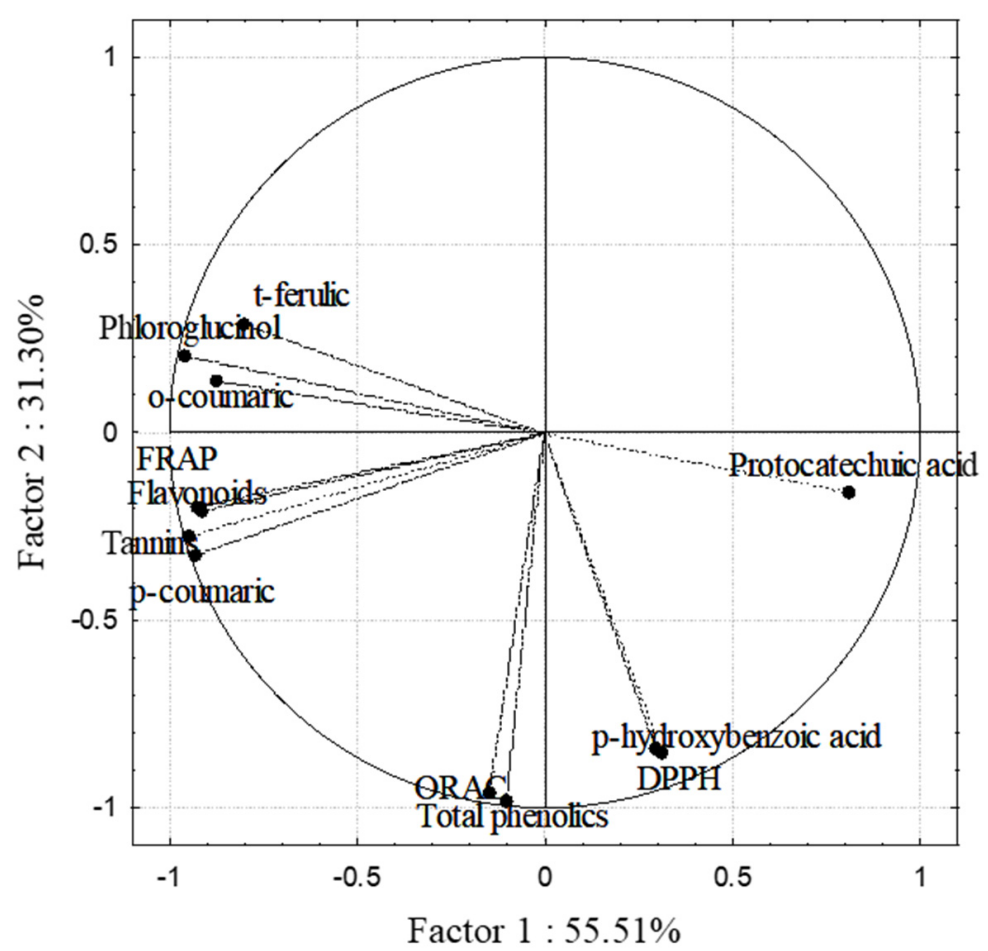

(a)

Figure 2. Cont. 


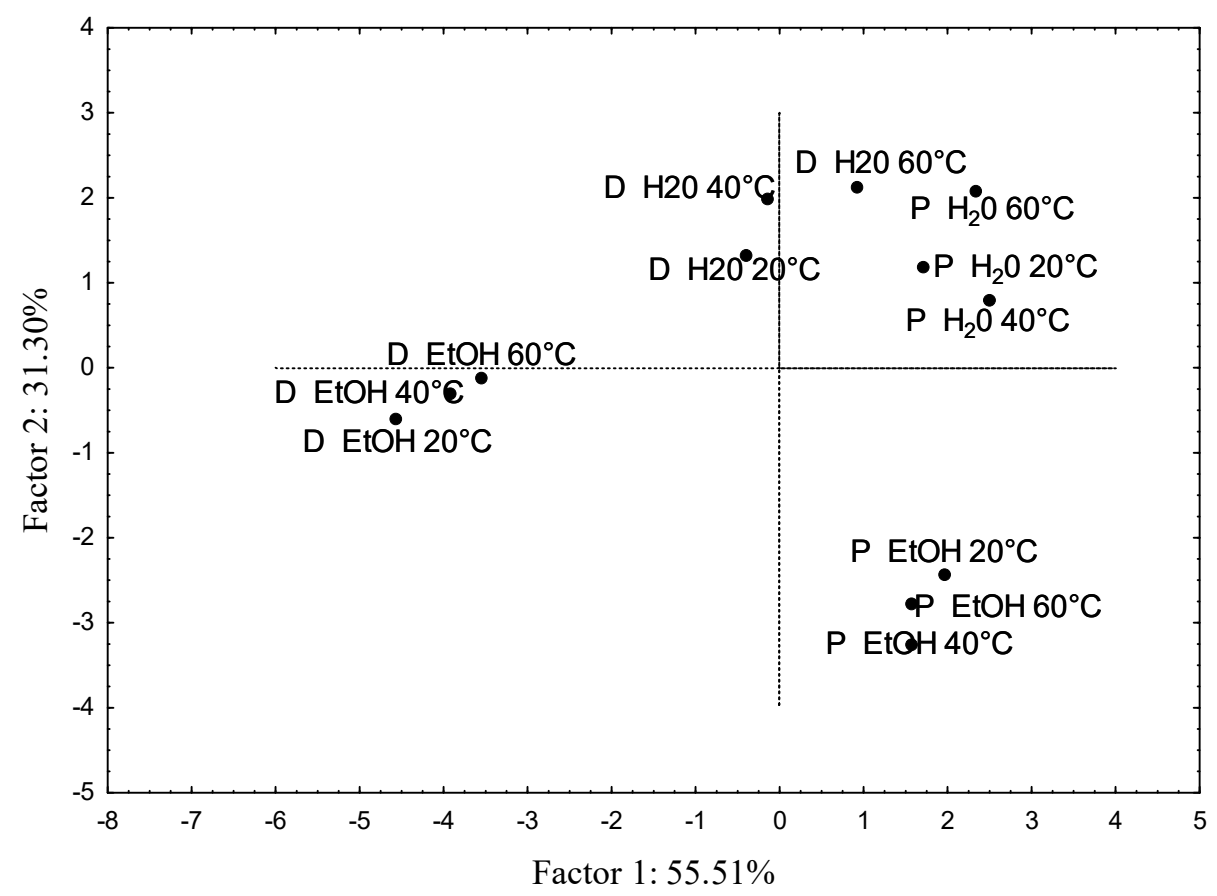

(b)

Figure 2. Correlation of the (a) loading plot and (b) score plot of the PCA.

The obtained results from the PCA are in accordance with the Pearson product moment correlations between variables that showed a high correlation between total phenolics and both FRAP $(r=0.8005, p=0.0018)$ and ORAC values $(r=0.9483, p<0.001)$, FRAP and phlorotannin content $(r=0.8951, p=0.001)$, flavonoids and tannins $(r=0.9744, p<0.001)$, flavonoids and reducing activity $(r=0.9739, p<0.001)$ and DPPH and ORAC $(r=0.8033$, $p=0.0017)$.

\section{Conclusions}

Brown algae are a valuable source of biologically active compounds. Research on the phenolic profile of the Adriatic algae D. dichotoma and P. pavonica is important for the interpretation of their biological potential and, therefore, for their potential use in the food, cosmetic and/or pharmaceutical industries. The results of this study also confirmed that the investigated algal species are a rich source of phenolics. The ethanolic extracts contained higher concentrations of phenolics, while the extraction temperature did not influence the extraction yield. D. dichtoma contained higher concentrations of hydroxycinnamic acid derivatives, while P. pavonica were richer in hydroxybenzoic acids. The tested extracts also showed good antioxidant potential using all three antioxidant assays, with flavonoids and tannins probably being responsible for this activity. This is still a relatively new scientific area, and further research should be directed toward the investigation of other extraction parameters or novel technologies focused on the yield of extracted bioactive compounds, especially phlorotannins. Furthermore, it would be interesting to investigate the other biological properties of brown algae extracts.

Author Contributions: Conceptualisation, I.G.M., V.Š. and D.S.; methodology, I.G.M. and D.S.; formal analysis, V.B., A.C., M.S., B.S., I.L. and M.Č.; data curation, I.G.M., D.S. and V.Š.; writing—original draft preparation, I.G.M.; writing—review and editing, V.Š., B.S., I.L., M.Č. and D.S.; supervision, I.G.M., D.S. and V.Š.; project funding acquisition, V.Šs. All authors have read and agreed to the published version of the manuscript.

Funding: This research was supported by the PRIMA program under Project BioProMedFood (Project ID 1467). The PRIMA program is supported by the European Union. 
Data Availability Statement: Data are available on request.

Acknowledgments: This research was supported by the PRIMA program supported by the European Union (Project BioProMedFood, ID 1467).

Conflicts of Interest: The authors declare no conflict of interest. The funders had no role in the design of the study; in the collection, analyses, or interpretation of data; in the writing of the manuscript; or in the decision to publish the results.

\section{References}

1. Cox, S.; Gupta, S.; Abu-Ghannam, N. Effect of different rehydration temperatures on the moisture, content of phenolic compounds, antioxidant capacity and textural properties of edible Irish brown seaweed. LWT Food Sci. Tech. 2012, 47, 300-307. [CrossRef]

2. Abdelhamid, A.; Jouini, M.; Amor, H.B.H.; Mzoughi, Z.; Dridi, M.; Said, R.B.; Bouraoui, A. Phytochemical analysis and evaluation of the antioxidant, anti-inflammatory, and antinociceptive potential of phlorotannin-rich fractions from three Mediterranean brown seaweeds. Marine. Biotechnol. 2018, 20, 60-74. [CrossRef] [PubMed]

3. Dixit, D.C.; Reddy, C.R.K.; Balar, N.; Suthar, P.; Gajaria, T.; Gadhavi, D.K. Assessment of the nutritive, biochemical, antioxidant and antibacterial potential of eight tropical macro algae along Kachchh Coast, India as human food supplements. J. Aquat. Food Prod. Technol. 2018, 27, 61-79. [CrossRef]

4. Lezcano, V.; Fernández, C.; Parodi, E.R.; Morelli, S. Antitumor and antioxidant activity of the freshwater macroalga Cladophora surera. J. Appl. Phycol. 2018, 30, 2913-2921. [CrossRef]

5. Generalić Mekinić, I.; Skroza, D.; Šimat, V.; Hamed, I.; Čagalj, M.; Popović Perković, Z. Phenolic content of brown algae (Pheophyceae) species: Extraction, Identification and Quantification. Biomolecules 2019, 9, 244. [CrossRef] [PubMed]

6. Alves, A.; Sousa, R.A.; Reis, R.L. A practical perspective on ulvan extracted from green algae. J. Appl. Phycol. 2013, 25, 407-424. [CrossRef]

7. Balboa, E.M.; Conde, E.; Moure, A.; Falqué, E.; Domínguez, H. In vitro antioxidant properties of crude extracts and compounds from brown algae. Food Chem. 2013, 138, 1764-1785. [CrossRef]

8. Van den Hoek, C.; Mann, D.G.; Jahns, H.M. Algae: An Introduction to Phycology; Cambridge University Press: Cambridge, UK, 1995.

9. Montero, L.; Herrero, M.; Ibanez, E.; Cifuentes, A. Separation and characterization of phlorotannins from brown algae Cystoseira abies-marina by comprehensive two-dimensional liquid chromatography. Electrophoresis 2014, 35, 1644-1651. [CrossRef]

10. Catarino, M.D.; Silva, A.; Cardoso, S.M. Fucaceae: A source of bioactive phlorotannins. Int. J. Mol. Sci. 2017, 18, 1327. [CrossRef]

11. Namvar, F.; Mohamad, R.; Baharara, J.; Zafar-Balanejad, S.; Fargahi, F.; Rahman, H.S. Antioxidant, antiproliferative, and antiangiogenesis effects of polyphenol-rich seaweed (Sargassum muticum). BioMed Res. Int. 2013, 604787. [CrossRef]

12. Li, Y.; Fu, X.; Duan, D.; Liu, X.; Xu, J.; Gao, X. Extraction and identification of phlorotannins from the brown alga, Sargassum fusiforme (Harvey) Setchell. Mar. Drugs 2017, 15, 49. [CrossRef]

13. Leyton, A.; Pezoa-Conte, R.; Barriga, A.; Buschmann, A.H.; Mäki-Arvela, P.; Mikkola, J.P.; Lienqueo, M.E. Identification and efficient extraction method of phlorotannins from the brown seaweed Macrocystis pyrifera using an orthogonal experimental design. Algal. Res. 2016, 16, 201-208. [CrossRef]

14. Le Lann, K.; Surget, G.; Couteau, C.; Coiffard, L.; Cerantola, S.; Gaillard, F.; Larnicol, M.; Zubia, M.; Guerard, F.; Poupart, N.; et al. Sunscreen, antioxidant, and bactericide capacities of phlorotannins from the brown macroalga Halidrys siliquosa. J. Appl. Phycol. 2016, 28, 3547-3559. [CrossRef]

15. Koivikko, R. Brown algal Phlorotannins: Improving and Applying Chemical Methods. Ph.D. Thesis, University of Turku, Turku, Finland, 22 February 2008.

16. Dominguez, H. Algae as a source of biologically active ingredients for the formulation of functional foods and nutraceuticals. In Functional Ingredients from Algae for Foods and Nutraceuticals; Dominguez, H., Ed.; Woodhead Publishing Series in Food Science, Technology and Nutrition; Woodhead Publishing: Cambridge, MA, USA, 2013.

17. Chojnacka, K.; Saeid, S.; Witkowska, Z.; Tuhy, Ł. Biologically active compounds in seaweed extracts-The prospects for the application. Open Conf. Proc. J. 2012, 3, 20-28. [CrossRef]

18. Ibañez, E.; Herrero, M.; Mendiola, J.A.; Castro-Puyana, M. Extraction and characterization of bioactive compounds with health benefits from marine resources: Macro and micro algae, cyanobacteria, and invertebrates. In Marine Bioactive Compounds; Hayes, M., Ed.; Springer: Boston, MA, USA, 2012; pp. 55-98.

19. Afonso, N.C.; Catarino, M.D.; Silva, A.M.S.; Cardoso, S.M. Brown macroalgae as valuable food ingredients. Antioxidants 2019, 8, 365. [CrossRef] [PubMed]

20. Kamenarska, Z.; Gasic, M.J.; Zlatovic, M.; Rasovic, A.; Sladic, D.; Kljajic, Z.; Stefanov, K.; Seizova, K.; Najdenski, H.; Kujumgiev, A.; et al. Chemical composition of the brown alga Padina pavonia (L.) Gaill. from the Adriatic Sea. Bot. Mar. 2002, 45, 339-345. [CrossRef]

21. Jerković, I.; Marijanović, Z.; Roje, M.; Kuś, P.M.; Jokić, S.; Čož-Rakovac, R. Phytochemical study of the headspace volatile organic compounds of fresh algae and seagrass from the Adriatic Sea (single point collection). PLoS ONE 2018, 13, e0196462. [CrossRef] [PubMed] 
22. Kosanić, M.; Ranković, B.; Stanojković, T. Brown macroalgae from the Adriatic Sea as a promising source of bioactive nutrients. J. Food Meas. Charact. 2019, 13, 330-338. [CrossRef]

23. Čagalj, M.; Skroza, D.; Tabanelli, G.; Özogul, F.; Šimat, V. Maximizing the antioxidant capacity of Padina pavonica by choosing the right drying and extraction methods. Processes 2021, 9, 587. [CrossRef]

24. Singleton, V.L.; Rossi, J. Colorimetry of total phenolics with phospho-molybdic-phosphotungstic acid reagents. Am. J. Enol. Viticul. 1965, 16, 144-158.

25. Yang, J.; Meyers, K.J.; Van der Heide, J.; Liu, R.H. Varietal differences in phenolic content and antioxidant and antiproliferative activities of onions. J. Agric. Food Chem. 2004, 52, 6787-6793. [CrossRef] [PubMed]

26. Julkunen-Titto, R. Phenolic constituents in the leaves of northen willow: Methods for the analysis of certain phenolics. J. Agric. Food Chem. 1985, 33, 213-217. [CrossRef]

27. Generalić Mekinić, I.; Šimat, V.; Ljubenkov, I.; Burčul, F.; Grga, M.; Mihajlovski, M.; Lončar, R.; Katalinić, V.; Skroza, D. Influence of the vegetation period on sea fennel phenolic composition, antioxidant and anticholinesterase activities. Ind. Crops. Prod. 2018, 124, 947-953. [CrossRef]

28. Benzie, I.F.F.; Strain, J.J. The ferric reducing ability of plasma (FRAP) as measurement of "antioxidant power": The FRAP assay. Anal. Biochem. 1996, 239, 70-76. [CrossRef]

29. Katalinić, V.; Smole Možina, S.; Generalić, I.; Skroza, D.; Ljubenkov, I.; Klančnik, A. Phenolic profile, antioxidant capacity and antimicrobial activity of crude leaf extracts of six Vitis vinifera L. varieties. Int. J. Food Prop. 2013, 16, 45-60. [CrossRef]

30. Shrestha, S.; Zhang, W.; Smid, S.D. Phlorotannins: A review on biosynthesis, chemistry and bioactivity. Food Biosci. 2021, 39, 100832. [CrossRef]

31. Garcia-Vaquero, M.; Ummat, V.; Tiwari, B.; Rajauria, G. Exploring ultrasound, microwave and ultrasound-microwave assisted extraction technologies to increase the extraction of bioactive compounds and antioxidants from brown macroalgae. Mar. Drugs 2020, 18, 172. [CrossRef]

32. Matanjun, P.; Mohamed, S.; Mustapha, N.M.; Muhammad, K.; Ming, C.H. Antioxidant activities and phenolics content of eight species of seaweeds from north Borneo. J. Appl. Phycol. 2008, 20, 367. [CrossRef]

33. Zubia, M.; Fabre, M.S.; Kerjean, V.; Le Lann, K.; Stiger-Pouvreau, V.; Fauchon, M.; Deslandes, E. Antioxidant and antitumoural activities of some Phaeophyta from Brittany coasts. Food Chem. 2009, 116, 693-701. [CrossRef]

34. Khaled, N.; Hiba, M.; Asma, C. Antioxidant and antifungal activities of Padina pavonica and Sargassum vulgare from the Lebanese Mediterranean coast. Adv. Environ. Biol. 2012, 6, 42-48.

35. Agregán, R.; Munekata, P.E.S.; Franco, D.; Dominguez, R.; Carballo, J.; Lorenzo, J.M. Phenolic compounds from three brown seaweed species using LC-DAD-ESI-MS/MS. Food Res. Int. 2017, 99, 979-985. [CrossRef] [PubMed]

36. Chkhikvishvili, I.D.; Ramazanov, Z.M. Phenolic substances of brown algae and their antioxidant activity. Appl. Biochem. Micro. 2000, 36, 289-291. [CrossRef]

37. Prior, R.L.; Wu, X.; Schaich, K. Standardized methods for the determination of antioxidant capacity and phenolics in foods and dietary supplements. J. Agric. Food Chem. 2005, 53, 4290-4302. [CrossRef] [PubMed] 